\title{
PENDEKATAN KONSEP DESAIN YANG MANUSIAWI GUNA MENINGKATKAN MINAT PENGGUNAAN JEMBATAN PENYEBERANGAN ORANG DI KOTA SURABAYA
}

\author{
Oleh : Raja Jusmartinah *)
}

\begin{abstract}
Abstrak
Beberapa tanggapan masyarakat melalui media massa menyebut bahwa faktor-faktor yang sangat berpengaruh terhadap penggunaan jembatan penyeberangan orang adalah (1) kesadaran masyarakat Kota Pahlawan untuk memanfaatkan jembatan penyeberangan sebagai sarana menyeberang jalan masih rendah, padahal jembatan-jembatan itu dibangun oleh Pemkot Surabaya untuk keselamatan jiwa warganya dan menelan duit yang tak sedikit, (2) desain Konstruksi Jembatan Penyeberangan (JP) yang tinggi dan tangga yang terjal dan sempit, keadaan yang kotor dan suram, sehingga pengguna merasa lelah dan tidak nyaman, selain itu tidak adanya desain yang terintegrasi antara jembatan dan pedestrian maupun halte (3) penempatan jembatan penyeberangan pada lokasi yang ramai dan benar-benar dibutuhkan oleh masyarakat sehingga tidak terkesan hanya untuk memenuhi kebutuhan pemasangan iklan semata.

Penelitian ini mencoba mencari jawaban melalui studi terhadap fisik jembatan penyeberangan yang ada di Kota Surabaya, mencari penyebab-penyebab kurangnya minat masyarakat dalam menggunakan jembatan penyeberangan dan usulan masyarakat terhadap desain jembatan penyeberangan. Karena jembatan penyeberangan merupakan fasilitas publik maka sudah sewajarnyalah konsep desain jembatan penyeberangan juga mengacu pada keinginan dan kebutuhan masyarakat pengguna.
\end{abstract}

Kata Kunci : Konsep Desain, Manusiawi, Jembatan Penyeberangan

\section{PENDAHULUAN}

1.1. Kondisi Jembatan Penyeberangan di Surabaya

Sebagai kota terbesar kedua di Indonesia Surabaya sedini mungkin harus mengatur tata ruang penggunaan lahan yang ada. Untuk bidang transportasi rencana pemerintah kota Surabaya akan mengoperasikan busway yang diperkirakan menelan biaya sekitar Rp. 89,9 miliar. Anggaran sebesar itu antara lain untuk biaya pembebasan lahan dan pembangunan depo seluas $9.500 \mathrm{~m} 2$, pembangunan 47 halte, JPO (jembatan penyeberangan orang), biaya penunjang operasional 100 pegawai, sosialisasi kepada 5000 orang, dan lima kegiatan supervisi pembangunan. Rute busway dirancang mulai bundaran Aloha hingga Tanjung Perak. Panjang koridor sekitar $40,7 \mathrm{~km}$ dengan satu terminal dan 47 halte. Jarak antar halte sekitar 500 meter. Juga ada penambahan 36 unit JPO dan perbaikan 7 unit JPO. Rute busway meliputi JI Ahmad Yani Wonokromo - Raya Darmo - Urip Sumoharjo Basuki Rahmat - Embong Malang - Panglima Sudirman (Jawa Pos, 15 November 2007).

Namun dana besar yang digunakan untuk pembangunan Jembatan Penyeberangan Orang tidak dimanfaatkan semaksimal mungkin karena pada kenyataannya banyak jembatan penyeberangan di jalan - jalan utama di Surabaya yang tidak digunakan.

\subsection{Lokasi Penelitian}

Adapun lokasi jembatan penyeberangan yang menjadi titik survey ada di 6 titik di kota Surabaya yaitu 3 titik di sepanjang jalan A. Yani, 2 titik di Pasar Wonokromo (DTC), 1 titik di jalan Diponegoro, dan 1 titik di jalan Pemuda. Pemilihan lokasi survey dilakukan secara random dan dilakukan pada saat lalu lintas padat yaitu pagi jam 7.00 wib sampai jam 9.00 wib dan sore hari pada jam 16.00 wib sampai jam 18.00 wib.

\subsection{Perumusan Masalah}

Beberapa permasalahan yang berkaitan dengan kajian desain yang berpengaruh terhadap minat masyarakat dalam menggunakan jembatan penyeberangan orang di kota Surabaya, yaitu:

1. Bagaimana konsep rancangan jalur jembatan penyeberangan orang yang terintegrasi dengan jalur pedestrian, sehingga dapat menjadi jalur sirkulasi kota yang saling mendukung. 
*) Dosen Perencanaan Wilayah \& Kota (PWK)

Universitas PGRI Adi Buana - Surabaya

2. Bagaimana konsep rancangan fisik jembatan penyeberangan orang yang sesuai dengan kebutuhan masyarakat Surabaya sebagai pengguna, sehingga tidak menimbulkan keterpaksaan dalam menggunakannya.

\subsection{Tujuan dan Manfaat Penelitian}

Penelitian ini diharapkan dapat memberi masukan dan acuan bagi berbagai pihak dalam membangun dan memperbaiki jembatan penyeberangan orang di Surabaya, yaitu:

1. Membuat konsep rancangan jalur jembatan penyeberangan orang yang terintegrasi dengan jalur pedestrian, sehingga menjadi jalur sirkulasi kota yang saling mendukung yang berdasarkan pada aspirasi masyarakat kota Surabaya.

2. Membuat konsep rancangan fisik jembatan penyeberangan orang yang sesuai dengan kebutuhan masyarakat Surabaya sebagai pengguna, sehingga tidak menimbulkan keterpaksaan dalam menggunakannya.

\section{TINJAUAN PUSTAKA}

\subsection{Peran Serta Masyarakat dalam Perencanaan Jalur Penyeberangan Orang}

Rancangan tata ruang perkotaan merupakan perancangan yang membutuhkan pelibatkan masyarakat kota itu sendiri sebagai pengguna, sehingga masyarakat haruslah ditempatkan sebagai subjek dari perencanaan bukan objek perencanaan seperti yang biasa terjadi. Bentuk peran serta masyarakat dalam perencanaan tata ruang perkotaan seperti yang tertuang dalam Peraturan Pemerintah Nomor 69 tahun 1996 bahwa:

a. Dalam perencanaan tata ruang masyarakat berhak memberikan masukan berupa informasi, saran, pertimbangan dan pendapat. Mengidentifikasi potensi dan persoalan, keberatan terhadap rencana, juga menjalin kerjasama dalam penelitian dan pengembangan serta memberikan bantuan teknis/kepakaran, dana dan bentuk bantuan lainnya.

b. Dalam pemanfaatan ruang, masyarakat dapat berperan dalam meningkatkan daya guna dan hasil guna, dan keserasian pemanfaatan ruang. Melaksanakan kegiatan pembangunan, mengubah pemanfaatan ruang sesuai rencana serta melindungi, memelihara dan meningkatkan kelestarian lingkungan. c. Dalam pengendalian pemanfaatan ruang, masyarakat dapat berperan dalam mengawasi dengan memberi informasi dan laporan serta memberi rekomendasi dan pertimbangan pada arah pembangunan.

\subsection{Jalur Penyeberangan Orang sebagai Ruang Publik Kota}

Dalam penelitian arsitek Jan Gehl (1996) dari Denmark, terdapat beberapa kategorisasi aktivitas masyarakat urban sebagai pengguna ruang publik kota yaitu: (1) 'necessity activities', di mana warga kota biasanya melakukan aktivitas di ruang publik, karena suatu keharusan. (2) 'optional social activities', di mana warga kota pada dasarnya mempunyai hasrat untuk melakukan aktivitas publik atau interaksi sosial secara sukarela. Untuk kategori ini biasanya aspek kualitas fisik, kenyamanan dan keamanan dari ruang publik selalu menjadi faktor dominan dalam menentukan keberhasilan aktivitas sukarela ini.

\subsection{Rancangan Fisik Jembatan Penyeberangan Orang}

2.3.1. Pedoman Teknis Perencanaan Jembatan Penyeberangan Orang

Berdasarkan Pedoman Perencanaan Jalur Pejalan Kaki pada Jalan Umum Nomor 032/T/BM/1999, disebutkan bahwa Jalur Pejalan Kaki dan perlengkapannya harus direncanakan sesuai ketentuan.

1) Pada hakekatnya pejalan kaki untuk mencapai tujuannya ingin menggunakan lintasan sedekat mungkin, dengan nyaman, lancar dan aman dari gangguan.

2) Adanya kontinuitas Jalur Pejalan Kaki, yang menghubungkan antara tempat asal ke tempat tujuan, dan begitu juga sebaliknya.

3) Jalur Pejalan Kaki harus dilengkapi dengan fisilitas-fasilitasnya seperti: rambu-rambu, penerangan, marka, dan perlengkapan jalan lainnya, sehinga pejalan kaki lebih mendapat kepastian dalam berjalan, terutama bagi pejalan kaki penyandang cacat.

4) Fasilitas Pejalan Kaki tidak dikaitkan dengan fungsi jalan.

5) Jalur Pejalan Kaki harus diperkeras dan dibuat sedemikian rupa sehingga apabila hujan permukaannya tidak licin, tidak terjadi genangan air, serta disarankan untuk dilengkapi dengan peneduh.

6) Untuk menjaga kesalamatan dan keleluasaan pejalan kaki, sebaiknya dipisahkan secara fisik dari jalur lalu lintas kendaraan.

7) Pertemuan antara jenis Jalur Pejalan 
Kaki yang menjadi satu kesatuan harus dibuat sedemikian rupa sehingga memberikan keamanan dan kenyamanan bagi pejalan kaki

\section{METODE PENELITIAN}

Strategi penelitian dilakukan melalui beberapa tahapan:

1. Pengumpulan Data atau informasi : yang paling penting untuk dikumpulkan dan dikaji dalam penelitian ini sebagian besar berupa data kualitatif. Informasi tersebut akan digali dari berbagai sumber data. Sumber data yang akan dimanfaatkan dalam penelitian ini antara lain:

a. Informan atau nara sumber, yang terdiri dari masyarakat pengguna jembatan penyeberangan orang di lokasi survey yang dipilih secara acak.

b. Data lokasi jembatan penyeberangan orang dengan mendeteksi volume lalu lintas jalan utama sebagai penentu kelayakan penempatan jembatan penyeberangan. Hal ini tentunya akan mempengaruhi volume orang yang menggunakan jembatan penyeberangan. Adapun lokasi jembatan penyeberangan yang menjadi titik survey ada di 6 titik di kota Surabaya yaitu 3 titik di sepanjang jalan A. Yani, 1 titik di Pasar Wonokromo (DTC), 1 titik di jalan Basuki Rahmad, dan 1 titik di jalan Pemuda. Pemilihan lokasi survey dilakukan secara random dan dilakukan pada saat lalu lintas padat yaitu pagi jam 7.00 wib sampai jam 9.00 wib dan sore hari pada jam 16.00 wib sampai jam 18.00 wib.

2. Teknik Pengumpulan Data

a. Penyebaran kuesioner pada pengguna jembatan penyeberangan b. Observasi langsung yang dilaksanakan dengan cara formal maupun informal, untuk mengamati berbagai kegiatan dan peristiwa yang terjadi dikawasan tersebut.

c. Mencatat Dokumen (Content Analysis) untuk mengumpulkan data yang bersumber dari dokumen dan arsip yang memuat tentang ketentuan teknis dan persaratan besaran ruang gerak manusia .

\section{Validitas Data}

Berhubung data/informasi yang digunakan beraneka ragam, bersifat multiside (Miles dan Huberman, 1984:132), maka untuk menjamin kebenarannya digunakan validitas data yang dikenal dengan teknik triangulasi.

\section{Teknik Analisis Data}

Teknik analisis yang digunakan adalah teknik analisis interaktif (Miles dan Huberman, 1984;79).

\section{HASIL DAN PEMBAHASAN}

Animo penggunaan Jembatan Penyeberangan Orang di Kota Surabaya, dirasakan masih belum maksimal. Hal ini disebabkan dari beberapa faktor yang membuat orang enggan untuk menyeberang menggunakan Jembatan Penyeberangan Orang. Faktor-faktor tersebut antara lain: kenyamanan, keselamatan, keamanan dan faktor lainnya sesuai dengan titik lokasi Jembatan Penyeberangan Orang (JPO) terebut berada. Untuk lebih detail, pembahasan ini akan dijabarkan sesuai dengan lokasi tempat JPO berada sesuai dengan pemilihan lokasi secara acak di Kota Surabaya. 


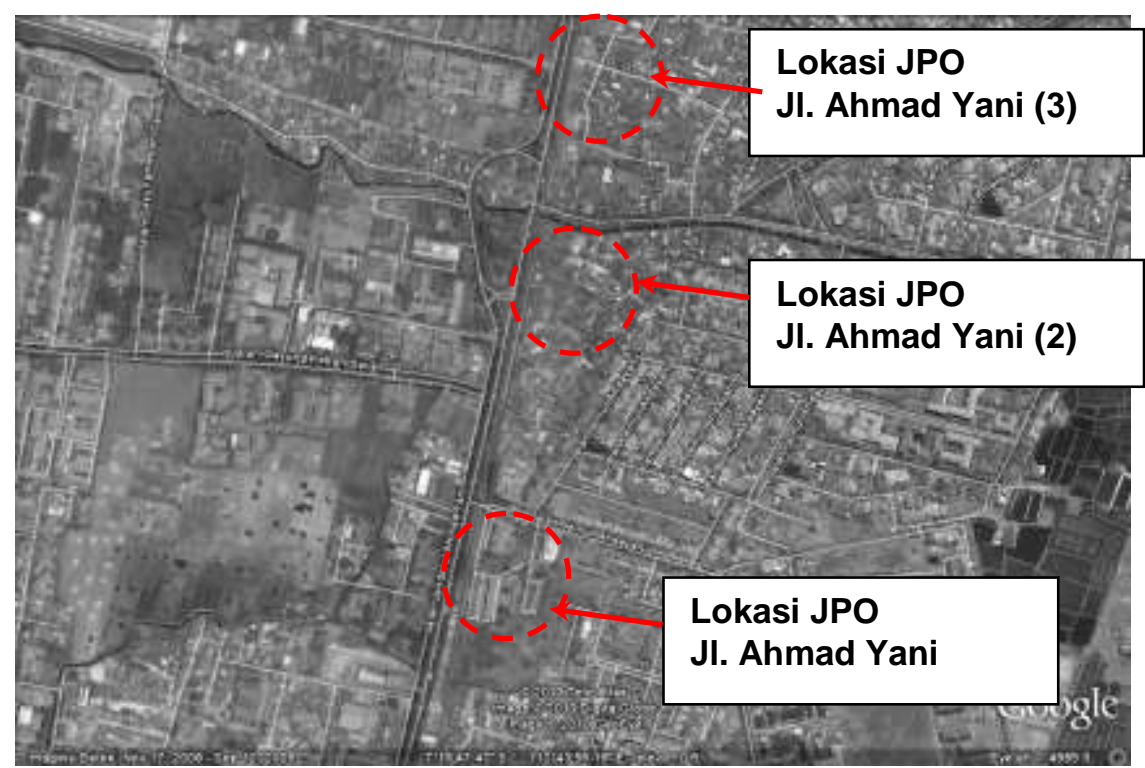

Gb. 1. Lokasi JPO Jl. Ahmad Yani Sumber: Observasi

4.1. Jembatan Penyeberangan Orang (JPO) Jalan Ahmad Yani (1) Mandiri.

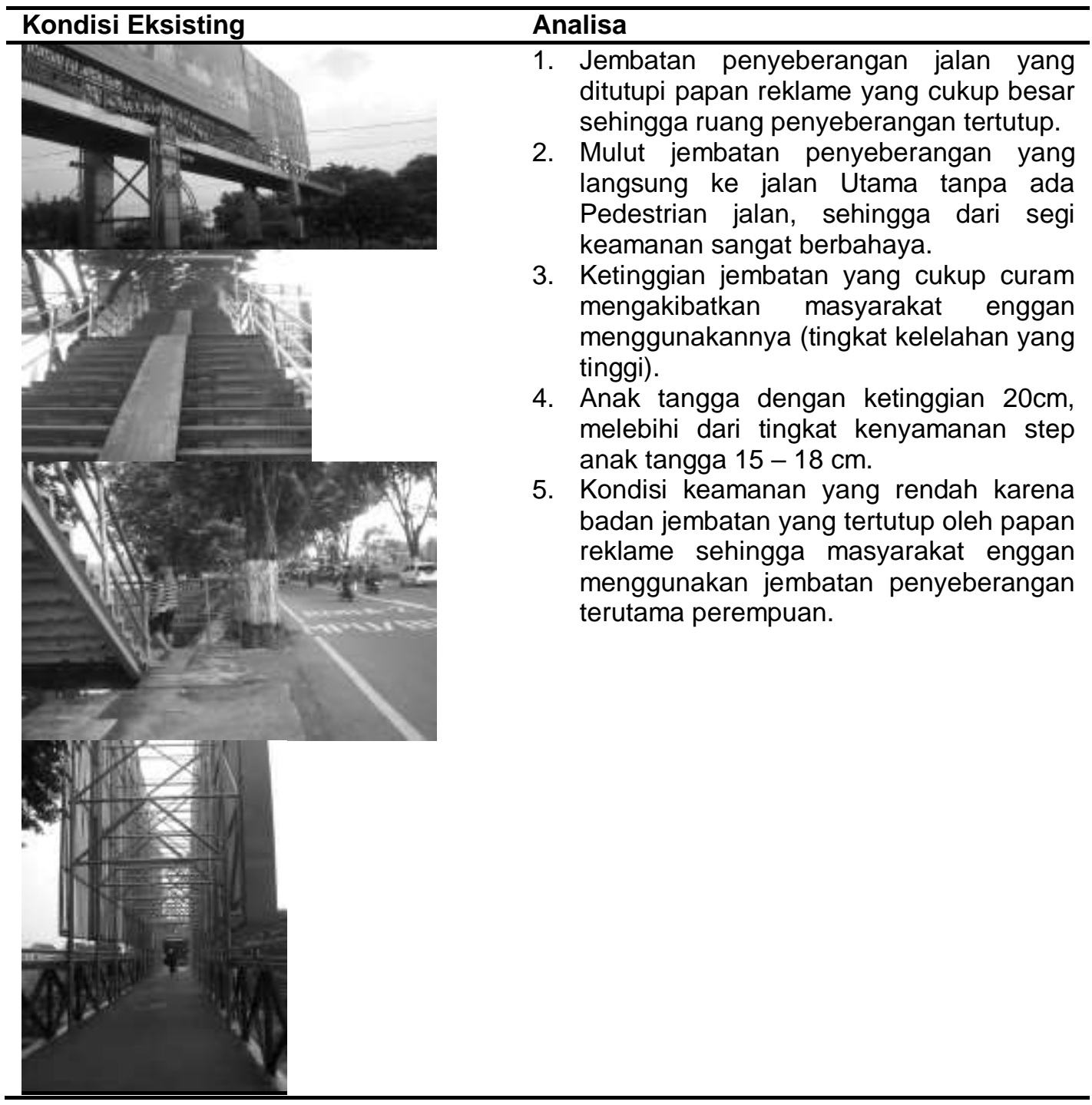


Raja Jusmartinah : Pendekatan Konsep Desain Yang Menusiawi Guna Meningkatkan Minat Penggunaan Jembatan Penyeberangan Orang di Kota Surabaya

5.2. Jembatan Penyeberangan Orang (JPO) Jalan Ahmad Yani (2) Bulog.

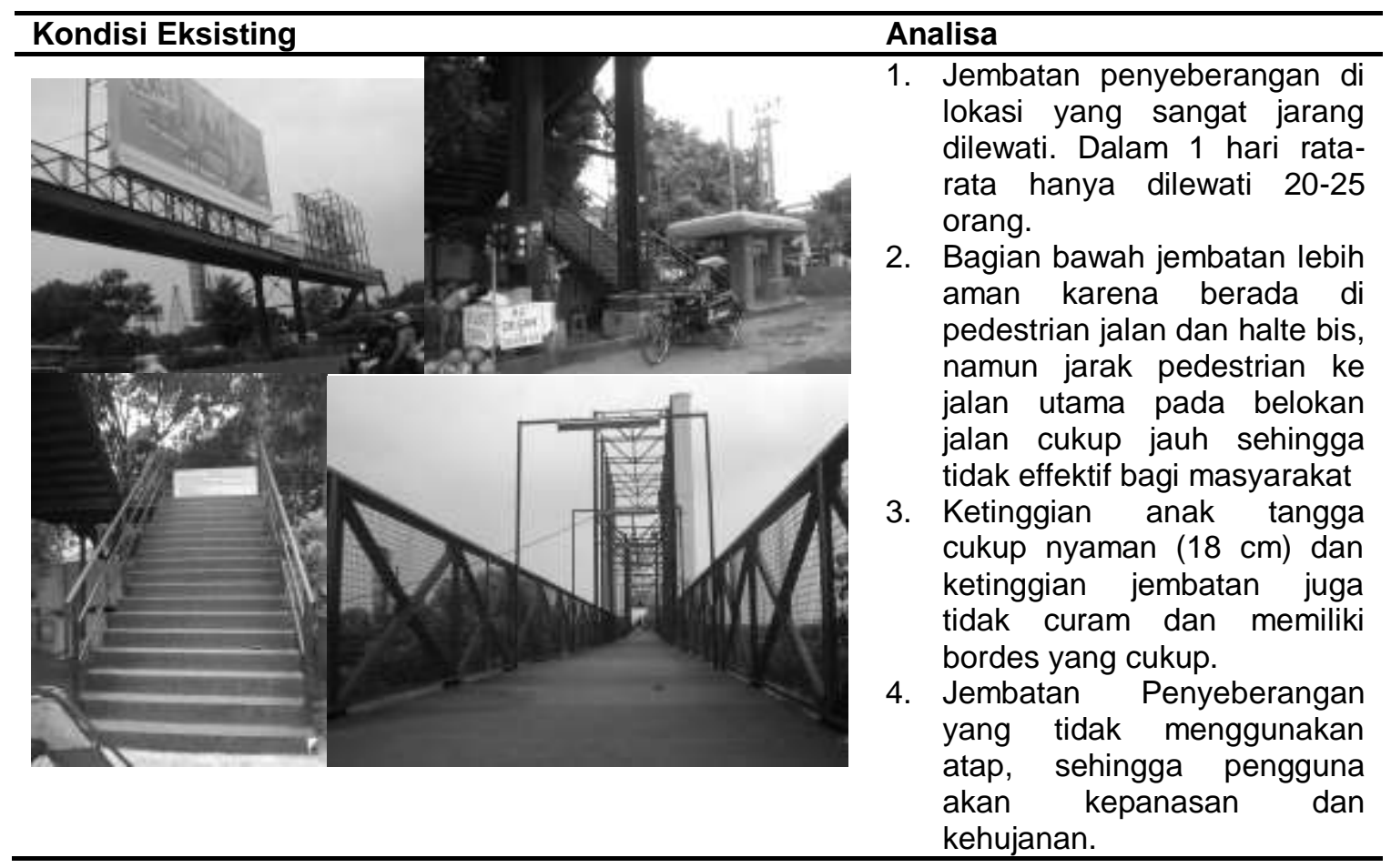

\subsection{Jembatan Penyeberangan Orang (JPO) Jl. Ahmad Yani (3) Ubhara}

\begin{tabular}{|c|c|}
\hline Kondisi Eksisting & Analisa \\
\hline 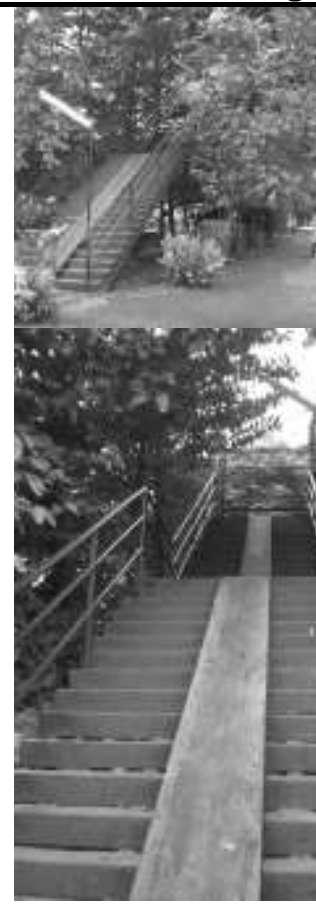 & $\begin{array}{l}\text { 1. Ketinggian anak tangga cukup } \\
\text { landai dan lebar yang mencukupi } \\
\text { ( } 2 \text { meter). Lokasi cukup ramai } \\
\text { sehingga jembatan ini cukup } \\
\text { sering digunakan masyarakat. } \\
\text { 2. Jembatan Penyeberangan yang } \\
\text { cukup ramai digunakan } \\
\text { masyarakat, cukup terbuka } \\
\text { walaupun tetap ditutupi papan } \\
\text { iklan. } \\
\text { 3. Ketinggian jembatan yang cukup } \\
\text { landai dan bordes yang memadai } \\
\text { cukup nyaman digunakan. } \\
\text { 4. Jembatan penyeberangan tanpa } \\
\text { penutup atap yang meyebabkan } \\
\text { pengguna kepanasan dan } \\
\text { kehujanan. Pagar yang kurang } \\
\text { tinggi dan kurang aman } \\
\text { 5. Jembatan sudah dilengkapi } \\
\text { dengan penerangan yang cukup, } \\
\text { mulut jebatan pada pedestrian } \\
\text { sehingga dari segi keamanan } \\
\text { cukup baik }\end{array}$ \\
\hline
\end{tabular}


5.4. Jembatan Penyeberangan Orang (JPO) DTC Wonokromo - Stasiun

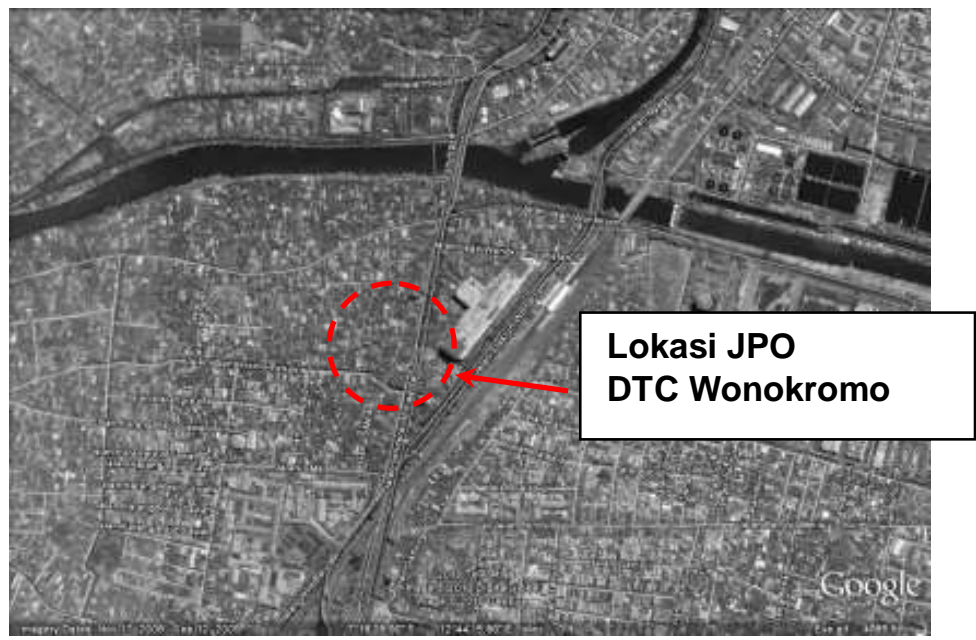

\section{Gb. 2. Lokasi JPO DTC Wonokromo} Sumber: Observasi

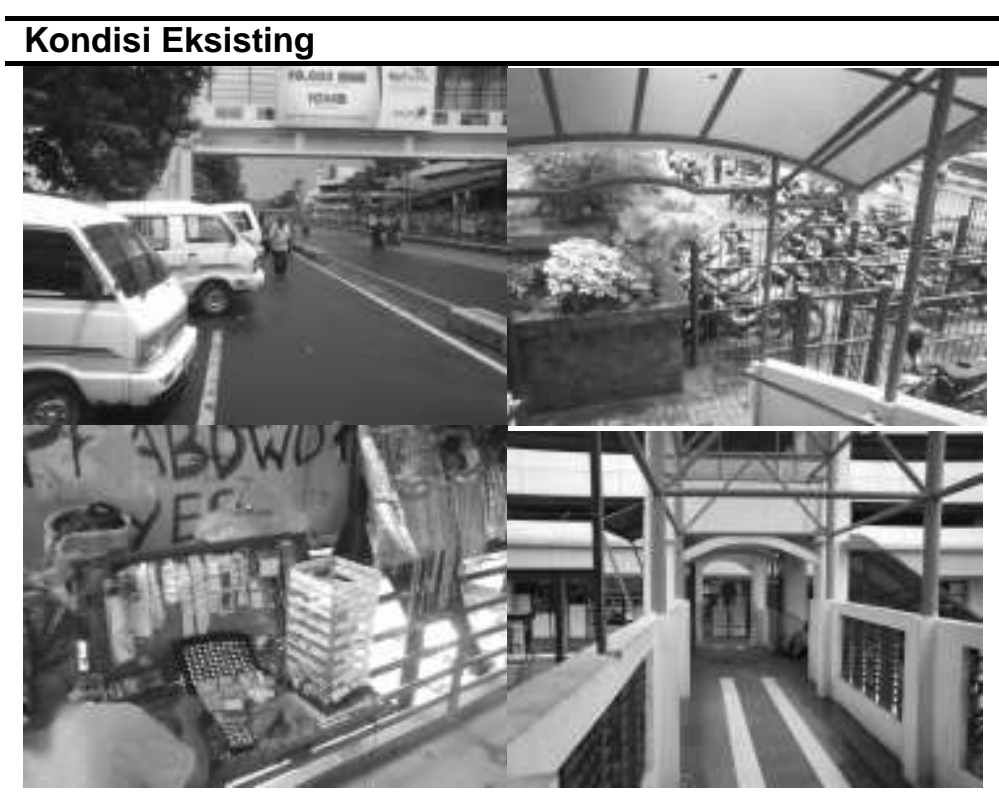

Analisa

1. Jembatan penyeberangan yang menghubungkan Pusat Grosir DTC dan stasiun Wonokromo. Dilewati oleh cukup banyak pengguna dan lokasi yang strategis.

2. Jembatan penyeberangan yang terbuat dari pasangan bata-beton yang cukup kokoh dan memiliki penutup atap untuk melindungi pengguna dari panas dan hujan.

3. Pada sudut-sudut jembatan digunakan berjualan oleh pedagang kaki lima yang semakin mempersempit ruang pergerakan pejalan kaki.

4. Mulut jembatan penyeberangan berhubungan langsung dengan pedestrian dan parkir sehingga cukup aman bagi pengguna jalan. 
5.5. Jembatan Penyeberangan Orang (JPO) Jl. Diponegoro

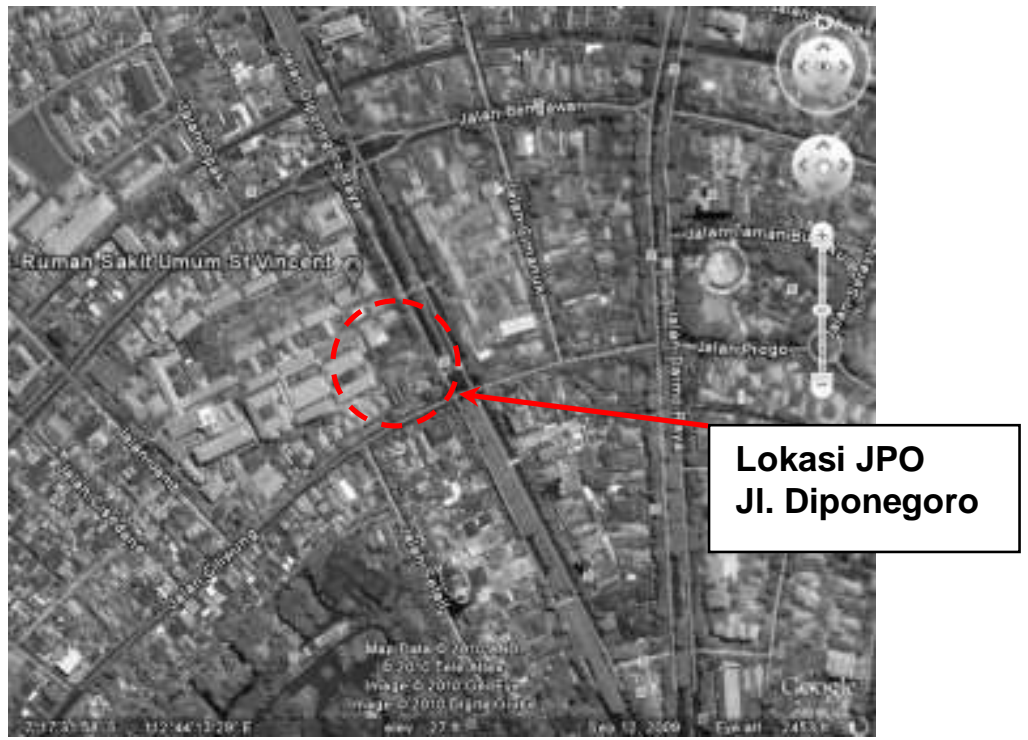

Gb. 3. Lokasi JPO Jl. Diponegoro

Sumber: Observasi

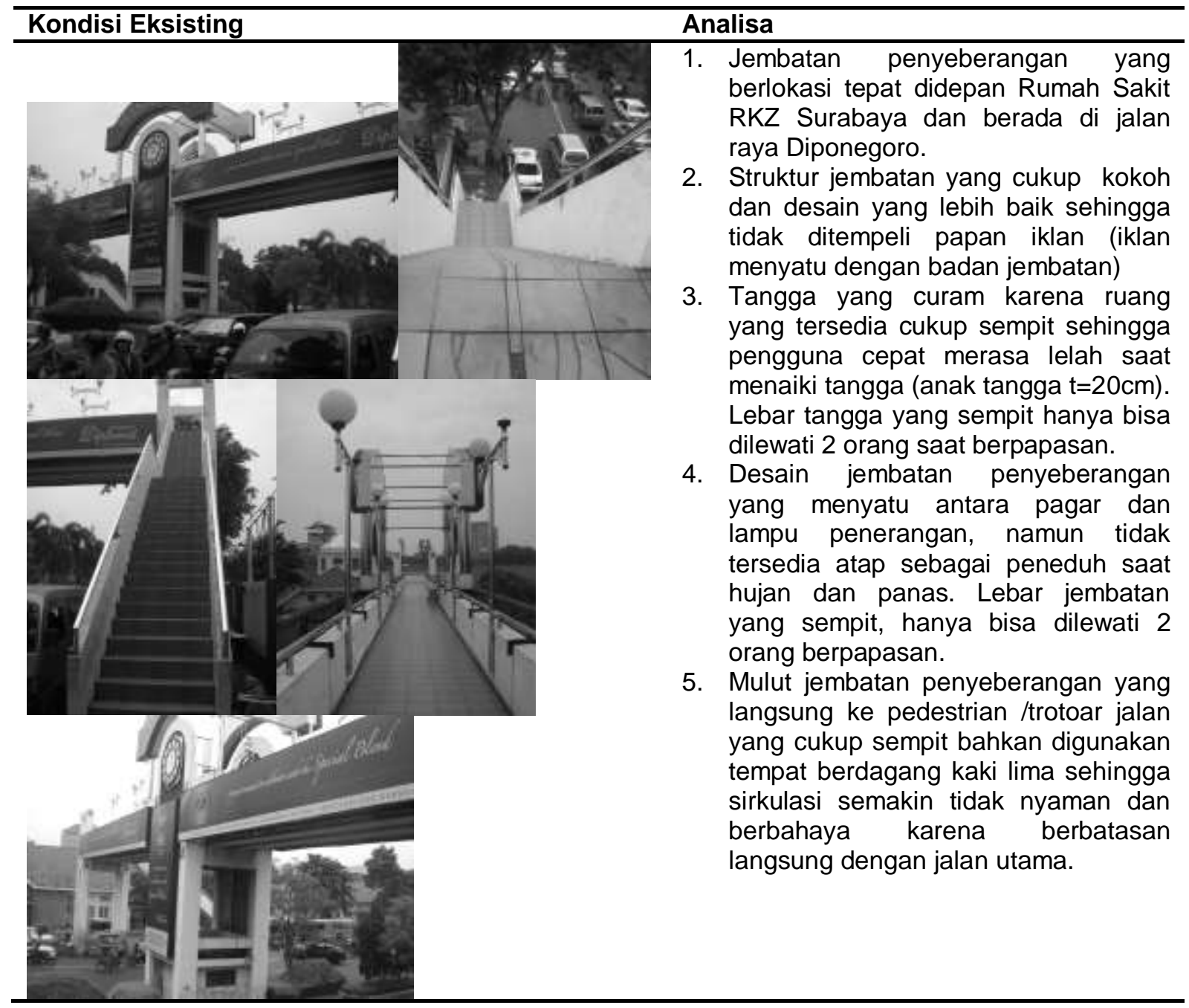




\subsection{Jembatan Penyeberangan Orang (JPO) DTC Jl.. Raya Wonokromo}

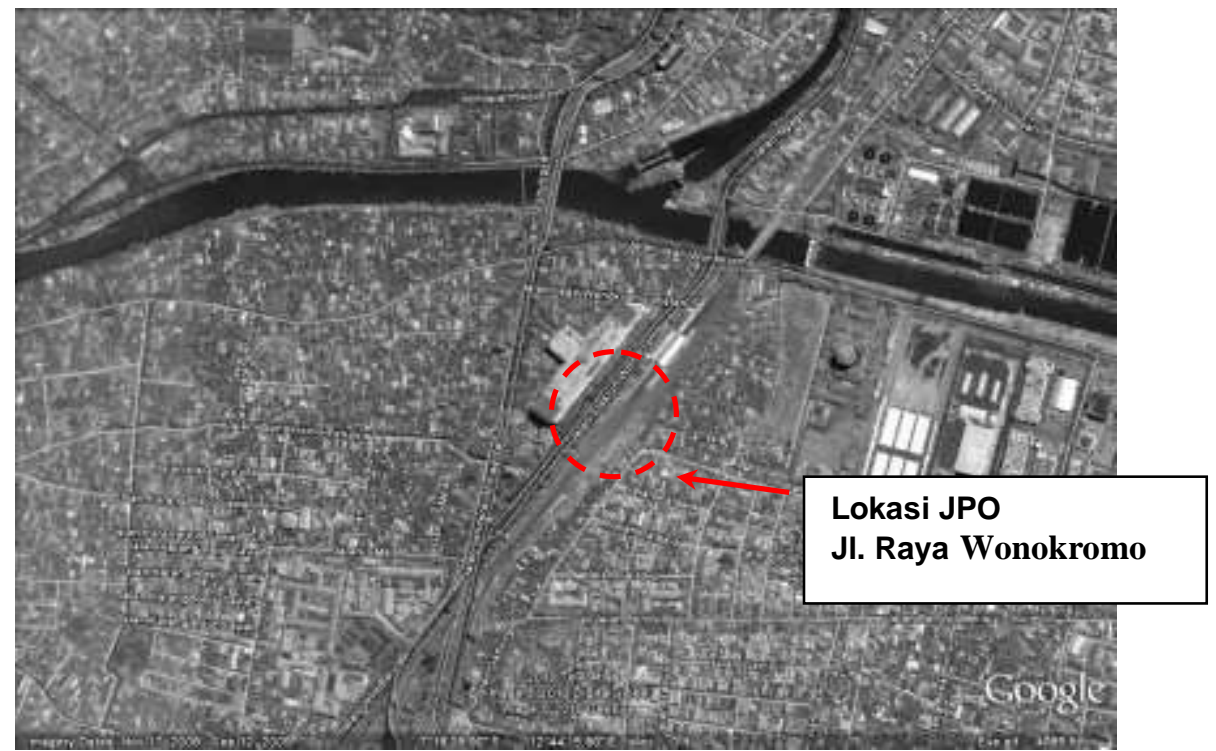

\section{Gb. 4. Lokasi JPO Jl. Raya Wonokromo} Sumber: Observasi

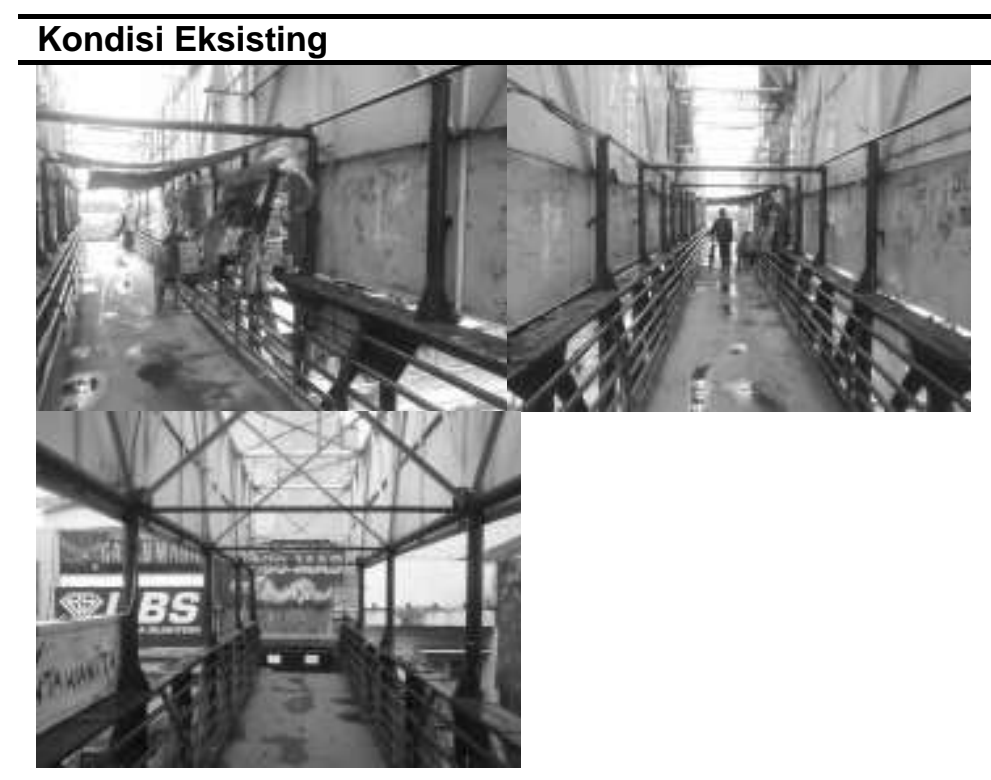

Analisa

1. Jembatan penyeberangan yang menghubungkan pusat grosir DTC dan terminal . Kondisi jembatan penyeberangan yang memprihatinkan dengan jarak yang sempit dan tertutup papan iklan, bahkan digunakan sebagai tempat berdagang.

2. Kondisi jembatan penyeberangan yang sempit dan tertutup oleh papan reklame, sehingga tidak memberi rasa aman dan tanpa lampu penerangan saat malam hari.

3. Bagia embatan penyebarangan yang tidak memiliki penutup atap sebagai pelindung dari panas dan hujan.

\section{SIMPULAN DAN USULAN DESAIN \\ 5.1. Simpulan}

Dari hasil analisis terhadap bentuk fisik jembatan penyeberangan pada 6 titik yang disurvey, dan hasil kuesioner yang dibagikan pada pengguna jembatan penyeberangan, didapat beberapa faktor yang menyebabkan kurangnya minat pengguna terhadap jembatan penyeberangan yaitu:

1. Faktor Kenyamanan

Masyarakat merasa kurang nyaman karena lebar jembatan yang sempit sehingga pengguna jembatan merasa tidak leluasa saat berjalan bersama teman, terutama saat menggandeng anak. Selain lebar jembatan, ketinggian anak tangga juga sangat mempengaruhi pengguna jembatan karena tinggi anak tangga yang cukup lebar, sehingga pengguna cepat merasa lelah. Ketersediaan atap sebagai pelindung dari panas dan hujan juga menjadi salahsatu faktor penentu kenyamanan pada jembatan penyeberangan.

2. Faktor Keamanan

Walaupun di beberapa jembatan penyeberangan telah menggunakan CCTV, namun faktor keamanan juga disebabkan oleh ketersediaan penerangan jembatan penyeberangan, struktur konstruksi jembatan dan bahan bangunannya. 
Namun, selain keamanan secara fisik kemanan pengguna juga lebih pada perasaan aman terhadap kejahatan yang sering terjadi pada jembatan penyeberangan karena kondisi jembatan yang tertutup oleh papan reklame dan kesan suasana yang tidak aman yang ditimbulkan terutama bagi pengguna perempuan.

3. Desain yang Menarik

Selain desain konstruksi yang kuat, nyaman, dibutuhkan juga desain yang menarik sehingga tampilan jembatan penyeberangan secara psikologis tidak berkesan 'angker'. Hal ini tentunya akan meningkatkan minat pengguna jembatan penyeberangan.

\subsection{Usulan Desain}

Dari faktor-faktor yang menyebabkan kurangnya minat pengguna jembatan penyeberangan, dan usulan masyarakat dari hasil angket yang disebarkan, maka ada halhal yang harus diperhatikan dalam membuat desain jembatan penyeberangan antara lain:

1. Mempelajari kondisi dan lokasi tempat jembatan tersbut ditempatkan, karena hal ini sangan mempengaruhi karakter pengguna yang tentunya akan berbeda kebutuhan dan fasilitas yang harus disediakan pada jembatan penyeberangan tersebut, misalnya penerangan yang lebih baik bagi jembatan yang sering digunakan pada malam hari.

2. Memenuhi standard yang telah ditentukan dan selalu mengadakan evaluasi dan pemeliharaan badan jembatan baik ketinggian anak tangga, railing, lampu penerangan dan sebagainya.

3. Menyediakan penutup atap agar pengguna terlindung dari panas dan hujan.

4. Mulut jembatan penyeberangan tidak langsung ke jalan rata, namun terintegrasi dengan pedestrian.

\section{DAFTAR PUSTAKA}

Anderson, Stanford (1986) On Streets. Cambridge, Massachusetts, and London: The MIT Press.

Ashihara, Yoshinobu (1981). Exterior Design in Architecture. Van Nostrand Reinhold. New York.

Ching,, Francis D. K (2000). Arsitektur: Bentuk, Ruang dan Tatanan, Alih Bahasa oleh Nurahma

Tresani Harwadi, Editor : Hilarius W. Hardani, Erlangga Jakarta

Departemen Pekerjaan Umum, Pedoman Perencanaan Jalur Pejalan Kaki pada Jalan Umum, Pedoman Teknik Nomor 032/T/BM/1999

Heri Suryanto and Rudianto, Faktor-faktor yang mempengaruhi pejalan kaki dalam memanfaatkan jembatan penyebrangan di Surabaya, Petra Christian University, Thesis 1999

Kamil , M. Ridwan,Assoc. AIA, Forgotten Space: Fenomena Koridor Jalan yang Terabaikan sebagai Ruang Publik Kota, Info URDI Vol. 17

Madanipour, Ali (1996). Design of Urban Space: An Inquiry into a Socio-spatial Process. West

Moleong, Lexi J. Metodologi Penelitian Kualitatif (2000), P. T. Remaja Rosdakrya, Bandung

Ronald Wiedenhoeft (1981), Cities for People, Van Nostrand Reinhold Company

Vernez Moudon, Anne, (1987). Public Streets for Public Use, New York: Van Nostrand Reinhold Company.

www./Detik/Surabaya/Jembatan-Penyeberangan-Dicuekin,Nyawa Dipertaruhkan.htm.

http://alhikmahlibrary.org,Perpustakaan/Online/Al-Hikmah/SURABAYA-BERBENAH-DIRI.htm (Jumat, 23 Nopember 07)

www.Detik / Surabaya / Meski - Ketinggian - Diukur - Ulang,Videotron - Jalan terus.htm $\underline{\text { Selasa, 11/12/2007) }}$ 